\title{
Protective immunity induced by peptides of AMA1, RON2 and RON4 containing T-and B-cell epitopes via an intranasal route against toxoplasmosis in mice
}

Tie-E Zhang ${ }^{1,2}$, Li-Tian Yin ${ }^{3}$, Run-Hua Li ${ }^{4}$, Hai-Long Wang ${ }^{1}$, Xiao-Li Meng ${ }^{1}$ and Guo-Rong Yin ${ }^{1 *}$

\begin{abstract}
Background: Toxoplasma gondii is a ubiquitous protozoan intracellular parasite, the causative agent of toxoplasmosis, and a worldwide zoonosis. Apical membrane antigen-1 (AMA1) and rhoptry neck protein (RON2, RON4) are involved in the invasion of T. gondii.

Methods: This study chemically synthesized peptides of TgAMA1, TgRON2 and TgRON4 that contained the T- and B-cell epitopes predicted by bioinformatics analysis. We evaluated the systemic response by proliferation, cytokine and antibody measurements as well as the mucosal response by examining the levels of antigen-specific secretory $\lg A(S \lg A)$ in the nasal, vesical and intestinal washes obtained from mice after nasal immunization with single (AMA1, RON2, RON4) or mixtures of peptides ( $A 1+R 2, A 1+R 4, R 2+R 4, A 1+R 2+R 4)$. We also assessed the parasite burdens in the liver and brain as well as the survival of mice challenged with a virulent strain.

Results: The results showed that the mice immunized with single or mixed peptides produced effective mucosal and systemic immune responses with a high level of specific antibody responses, a strong lymphoproliferative response and significant levels of gamma interferon (IFN- $\gamma$ ), interleukin-2 (IL-2) and IL-4 production. These mice also elicited partial protection against acute and chronic T. gondii infection. Moreover, our study indicated that mixtures of peptides, especially the A1 + R2 mixture, were more powerful and efficient than any other single peptides.

Conclusions: These results demonstrated that intranasal immunisation with peptides of AMA1, RON2 and RON4 containing T- and B-cell epitopes can partly protect mice against toxoplasmosis, and a combination of peptides as a mucosal vaccine strategy is essential for future Toxoplasma vaccine development.
\end{abstract}

Keywords: Toxoplasma gondii, AMA1, RON2, RON4, Peptide epitope, Mucosal vaccine

\section{Background}

Toxoplasma gondii is a significant obligate intracellular protozoan parasite because it infects a wide variety of warm-blooded animals, including humans [1]. Infection in humans can cause severe ocular, neurologic and sometimes systemic disease, especially in immunocompromised and congenitally infected individuals [2-4]. Toxoplasma gondii can sometimes be acquired congenitally by a newborn from an infected mother, congenital

\footnotetext{
* Correspondence: guorongyin@163.com

'Research Institute of Medical Parasitology, Shanxi Medical University, Xinjian South Road, Taiyuan, Shanxi Province 030001, China

Full list of author information is available at the end of the article
}

toxoplasmosis may cause abortion, neonatal death or fetal abnormalities $[4,5]$. Currently, $T$. gondii control depends primarily on chemotherapy, but the available medicines have many severe side effects. The development of safe and effective vaccines is the best strategy to prevent toxoplasmosis [6,7].

Successful invasion is the first and important step for the parasite to infect the host cells. The invasion process by $T$. gondii involves a moving junction (MJ) formed between the apex of the parasite and the host cell membrane [4], and the MJ structure is used by $T$. gondii to propel itself inside the cell using a gliding motion. Apical membrane antigen-1 (AMA1) plays a central role during 
invasion of $T$. gondii [8-11] as a member of the moving junction complex $[12,13]$. Rhoptry neck protein 2 (RON2) is present not only at the nascent $\mathrm{MJ}$ [13] but also at the progressing MJ, where it co-localizes with other RON partners. Therefore, RON2 is present at the host cellparasite interface during the complete invasion process [14]. AMA1 uses the RON2 as a receptor, and the AMA1RON2 interaction is a key for invasion [14,15]. Moreover RON4 participates in MJ formation and is an indispensable component of the MJ complex $[12,13,16]$.

Because MJ components play an essential role in invasion by $T$. gondii, the proteins in the MJ structure may be potential vaccine candidates. AMA1 has been a key malaria vaccine candidate and induces antibodies that inhibit invasion and confer protection in animals [11,14]. In addition, a plasmid that encodes T. gondii AMA1 has been shown to generate a strong specific immune response and to provide effective protection against toxoplasmosis in mice [17]. Experimental studies revealed RON2 as a potential Plasmodium vaccine candidate [18]. Recent study has shown that a DNA vaccination that expresses RON4 and RON4 protein (RON4S2) induced immune responses, but failed to protect the mice against chronic toxoplasmosis [19]. The all above studies showed that AMA1, RON2 and RON4 might be potential vaccine antigens against toxoplasmosis.

Vaccine needs to include all the components capable of eliciting a protective immune response, notably the $\mathrm{T}$ and B- cell epitopes. Attempts to develop a peptide vaccine that contains $\mathrm{T}$ - and B-cell epitopes for $T$. gondii have shown encouraging results [20,21]. Since bioinformatics has played a significant role in the analysis of protein epitopes, structures and functions, we used bioinformatics to predict the T- and B-cell epitopes of TgAMA1, TgRON2 and TgRON4 in this study.

The natural site of $T$. gondii infection is the mucosal surface of the intestine, and effective protection may require both mucosal and systemic immune responses. The intranasal route acts as an interesting alternative vaccination route and promoted both systemic and mucosal immune responses to an antigen [22-25], which can be used to target pathogens that invade far from the immunization site, such as the intestines [26].

Although host cell invasion has been well described at the ultrastructural and molecular level, the immunogenicity and protective efficacy of AMA1, RON2 and RON4 are still poorly understood. In this study, we predicted and synthesized the peptides of AMA1, RON2 and RON4 containing the T- and B-cell epitopes of T. gondii. We also comparatively evaluated the immune responses and protective efficacy of a single peptide of AMA1 (A1), RON2 (R2) or RON4 (R4), mixtures of two peptides (A1 + R2, A1 + R4 or $\mathrm{R} 2+\mathrm{R} 4)$ and a mixture of three peptides $(\mathrm{A} 1+\mathrm{R} 2+\mathrm{R} 4)$ in $\mathrm{BALB} / \mathrm{c}$ mice via intranasal immunization for the first time.

\section{Methods}

\section{Epitopes prediction and peptides synthesis}

The secondary structure and the B cell epitopes of AMA1, RON2 and RON4 of Toxoplasma gondii were predicted by the bioinformatics software of the DNAStar Protean system and the Bcepred online prediction tool $[27,28]$.

Based on the results of these methods, we chose the peptides that have good hydrophilicity, satisfactory flexibility, high accessibility and strong antigenicity, but not the $\alpha$-helix and $\beta$-folded sheets, which do not easily interact with antibodies and generally do not act as epitopes. We also predicted the potential B cell epitopes of TgAMA1, TgRON2 and TgRON4 by using the DNAMAN v6 software [29]. We used the online service SYFPEITHI (http://www.syfpeithi.de/bin/MHCServer.dll/ EpitopePrediction.htm) to predict the Th cell epitopes of TgAMA1, TgRON2 and TgRON4. Based on the results obtained with these methods, the overlap regions of the predicted results were regarded as the potential T/B combined epitopes of TgAMA1, TgRON2 and TgRON4.

The chemically synthesized peptides listed in Table 1 were obtained from a peptide specialty laboratory (China Peptides Co., Ltd), which purified peptides by HPLC and verified their chemical identity by mass spectrometry. The concentrations of peptide solutions were determined via quantitative amino acid analysis using a Biochrom 20 Amino Acid Analyzer (Pharmacia Biotech). The purity of peptides was $>98 \%$ in the lyophilized form.

\section{Toxoplasma gondii strain}

The tachyzoites of the virulent $T$. gondii $\mathrm{RH}$ strain were used to challenge mice, and were provided by the Peking University Health Science Center (Beijing, China). The parasites were maintained and collected from the peritoneal cavity of infected specific-pathogen-free (SPF) $\mathrm{BALB} / \mathrm{c}$ mice as previously described $[24,25]$.

\section{Mice and ethics statement}

Female BALB/c mice were purchased from the Institute of Laboratory Animals, Chinese Academy of Medical

Table 1 The sequences of the peptides of T/B combined epitopes from $T$. gondii RH strain

\begin{tabular}{|c|c|c|c|c|}
\hline $\begin{array}{l}\text { Source of } \\
\text { peptide }\end{array}$ & $\begin{array}{l}\text { Amino acid } \\
\text { position }\end{array}$ & Sequences & $\begin{array}{l}\text { Numbers } \\
\text { of amino } \\
\text { acid }\end{array}$ & $\begin{array}{l}\text { Molecular } \\
\text { weight }\end{array}$ \\
\hline AMA1 & $41-55$ & CAELCDPSNKPGHLL & 15 & 1596.84 \\
\hline RON2 & 119-148 & $\begin{array}{l}\text { LTAGGPLPHGSWS } \\
\text { WSGTPPEVQTTGG } \\
\text { SQIS }\end{array}$ & 30 & 2993.26 \\
\hline RON4 & $343-374$ & $\begin{array}{l}\text { KEQFFQFLQHLSA } \\
\text { DYPKQVQTVYEFL } \\
\text { GWVADK }\end{array}$ & 32 & 3891.43 \\
\hline
\end{tabular}

"AMA1: Apical membrane antigen-1; RON2: Rhoptry neck protein 2; RON4: Rhoptry neck protein 4. 
Science (Beijing, China). All the mice were maintained under specific-pathogen-free conditions at the Centre of Laboratory Animals with a 12-hour light/dark cycle and provided with rodent feed and water ad libitum. The mice were acclimated for one week prior to the experiments. The animal protocols were approved by the Laboratory Animal Use and Care Committee of Shanxi Medical University (Permit No: SXMU-2011-16) and the Ethics Committee on Animal Research of the Shanxi Medical University (Protocol \#: 20110320-1). All surgery was performed under sodium pentobarbital anaesthesia, and all possible efforts were made to minimise suffering of experiment mice.

\section{Immunization and challenge}

A total of 176 female BALB/c mice aged 6 weeks were randomly divided into eight groups (22 mice per group). All mice were intranasally immunized with $30 \mu \mathrm{g}$ AMA1, $30 \mu \mathrm{g}$ RON2, $30 \mu \mathrm{g}$ RON4, $15 \mu \mathrm{g}$ AMA1 plus $15 \mu \mathrm{g}$ RON2 (A1 + R2), $15 \mu \mathrm{g}$ AMA1 plus $15 \mu \mathrm{g}$ RON4 $(\mathrm{A} 1+$ R4), $15 \mu \mathrm{g}$ RON2 plus $15 \mu \mathrm{g}$ RON4 (R2 + R4) or a mixture of three peptides $(10 \mu \mathrm{g}$ of each peptide, $\mathrm{A} 1+\mathrm{R} 2+\mathrm{R} 4)$. The peptides were suspended in $20 \mu \mathrm{l}$ of sterile PBS, while control mice received $20 \mu \mathrm{l}$ of sterile PBS alone. Each dose of immunogen was instilled into the nostrils of mice with a micropipettor $(10 \mu \mathrm{l} /$ nostril). All animals were vaccinated three times on days 0,14 and 21 .

Two weeks after the final inoculation (on day 35), 6 mice in each group were anesthetized with sodium pentobarbital (1.5\%, $0.1 \mathrm{ml} / 20 \mathrm{~g}$ weight). Blood samples were collected from the mice in each group via retroorbital plexus puncture, and the sera were stored at $-70^{\circ} \mathrm{C}$ for further analysis. The spleens were collected under aseptic conditions to perform lymphocyte proliferation assays, and the culture supernatants were used for cytokine assays. Mucosal washes, including nasal, vesical and intestinal washes, were collected using PBS and stored at $-70^{\circ} \mathrm{C}$ for secretory IgA (SIgA) assays.

Two weeks after the last immunization, another 10 mice from each group were challenged orally (with a feeding needle) with a lethal dose $\left(4 \times 10^{4}\right.$ tachyzoites per mouse) of T. gondii RH strain. The symptoms and survival times of the challenged mice were monitored and recorded thrice daily for 30 days. To evaluate the effect of the immunization on the tissue tachyzoite burdens, the remaining 6 mice from each group were orally challenged with a nonlethal dose $\left(1 \times 10^{4}\right.$ tachyzoites per mouse) of $T$. gondii strain RH. On the 30th day after being challenged, the mice were anesthetized with sodium pentobarbital, and the numbers of tachyzoite in the livers and brains were measured using a sensitive real-time quantitative PCR (qRTPCR) method as previously described $[25,30]$.

For mice survival analysis, the infected mice were monitored at $8 \mathrm{am}, 2 \mathrm{pm}$ and $8 \mathrm{pm}$ daily regarding their physical appearance, such as displaying rough coat, decreases in appetite, weakness/inability to obtain feed or water and depression. When these conditions were observed, a mouse would be moved to an isolated cage for further husbandry; if obvious suffering, such as struggling or whining was observed, the mouse would be sacrificed through ether inhalation. No obvious suffering was observed in this study.

\section{Sera antibodies determination}

Antigen-specific IgA, IgG and IgG subclasses were analyzed by enzyme-linked immunosorbent assay (ELISA) as previously described [24]. Briefly, each well of a 96well microtiter plates was coated overnight at $4^{\circ} \mathrm{C}$ with $100 \mu \mathrm{l}$ peptide diluted in $0.05 \mathrm{M}$ carbonate buffer ( $\mathrm{pH}$ 9.6) at the optimal concentrations of $10 \mu \mathrm{g} / \mathrm{ml}$ for the AMA1, RON2 or RON4 groups, $12 \mu \mathrm{g} / \mathrm{ml}$ for the $\mathrm{A} 1+\mathrm{R} 2, \mathrm{~A} 1+\mathrm{R} 4$ and $\mathrm{R} 2+\mathrm{R} 4$ groups $(6 \mu \mathrm{g} / \mathrm{ml}$ each peptide) or $15 \mu \mathrm{g} / \mathrm{ml}$ for the $\mathrm{A} 1+\mathrm{R} 2+\mathrm{R} 4$ and control groups $(5 \mu \mathrm{g} / \mathrm{ml}$ each peptide). Murine sera diluted 1:300 in PBS was applied to the wells, and the plate was incubated at $37^{\circ} \mathrm{C}$ for $2 \mathrm{~h}$, followed by the addition of goat anti-mouse IgG- or IgA-horseradish peroxidase conjugated antibody as a secondary antibody (Sigma), which was diluted 1:2000 or 1:1000. To analyze the subclasses, the sera were diluted 1:300, applied to the plates and developed with goat anti-mouse IgG1- or IgG2ahorseradish peroxidase conjugated antibody (Proteintech Group, Inc., USA) diluted at 1:2000. The results were expressed as $\mathrm{OD}_{492}$ using an ELISA plate reader and determined in duplicate for each serum sample from at least two independent ELISAs.

\section{Spleen cell proliferation assay}

Spleen cell proliferation was assayed as previously described [25]. In brief, $5 \times 10^{5}$ cells per well were cultured in triplicate in 96-well plates containing RPMI-1640 medium supplemented with penicillin-streptomycin $(1 \mathrm{mM})$ and $10 \%$ fetal calf serum (FCS). The culture was stimulated with either $10 \mu \mathrm{g} / \mathrm{ml}$ of peptide, $5 \mu \mathrm{g} / \mathrm{ml}$ of concanavalin A (Con A) as a positive control or medium alone for proliferation. The plates were incubated in 5\% $\mathrm{CO}_{2}$ at $37^{\circ} \mathrm{C}$ for 4 days. Next, $10 \mu \mathrm{l}$ of CCK-8 reagent (Dojindo Laboratories, Japan) was added to each well, and the plate was incubated for $3 \mathrm{~h}$. The optical density was then determined at $450 \mathrm{~nm}$ using an ELISA reader. The spleen cell proliferative responses were quantitated using a stimulation index (SI), which was calculated as the ratio of the average $\mathrm{OD}_{450}$ of the stimulated cells to the average $\mathrm{OD}_{450}$ of the unstimulated cells.

\section{Spleen cell cultures and cytokine assays}

Splenocyte suspensions were prepared from six mice in each group 2 weeks after the last immunization, and 
$1.5 \times 10^{6}$ cells/well were cultured in 24-well plates in triplicate in RPMI-1640 containing 10\% FCS as described previously $[24,25]$. The culture was stimulated with $10 \mu \mathrm{g} / \mathrm{ml}$ peptide. The cell-free supernatants were harvested and assayed for interleukin-2 (IL-2) and IL-4 activities at $24 \mathrm{~h}$, while the IL-10 activity was assessed at $72 \mathrm{~h}$ and the interferon-gamma (IFN- $\gamma$ ) activity was assessed at $96 \mathrm{~h}$. The concentrations of IL-2, IL-4, IL-10 and IFN- $\gamma$ were determined by a commercial ELISA kit (PeproTech, USA) according to the instructions provided by the manufacturer. The sensitivity limits of detection of IL-2, IL-4, IL-10 and IFN- $\gamma$ were 16, 16, 47 and $23 \mathrm{pg} / \mathrm{ml}$, respectively.

\section{Mucosal washes collection and SIgA determination}

Prior to collecting the samples, the mice were deprived of food for $8 \mathrm{~h}$ to deplete the intestinal contents. Nasal washes were collected as described previously [25,31]. Briefly, the trachea was surgically exposed. A micropipette was then passed through the larynx and nasal cavity and a total of $0.6 \mathrm{ml}$ of sterile PBS was flushed five times (0.1 ml per time) per mouse. The intestinal washes were collected using previously described protocols [24,25,32]. The small intestine sample was washed with $3.0 \mathrm{ml}$ PBS. To collect the vesical washes, the bladder was exposed and rinsed gently with sterile PBS using the tip of a micropipette through the urethra. A total of $0.6 \mathrm{ml}$ of sterile PBS was flushed gently in and out of the bladder, and all fluids were collected by micropipette. The bladder was flushed six times $(0.1 \mathrm{ml}$ per flush). Every $0.1 \mathrm{ml}$ PBS was re-aspirated into the micropipette and reinjected into the bladder for a total of three cycles before final withdrawal.

All mucosal washes were centrifuged at $1000 \times g$ for $10 \mathrm{~min}$ at $4^{\circ} \mathrm{C}$ to remove any tissue, fecal matter and cellular debris and were stored at $-20^{\circ} \mathrm{C}$ until assayed. The titers of SIgA in the nasal, vesical and intestinal washes were also detected by ELISA at $492 \mathrm{~nm}$ as described above.

\section{Statistical analysis}

The mean of each variable (IgA, total IgG, IgG1, IgG2a, IFN- $\gamma$, IL-2, IL-4 and IL-10) was compared between the different groups using one-way ANOVA. All statistical analyses were performed using the SPSS software for Windows version 13.0. The differences were considered statistically significant at $P<0.05$. The tachyzoite burdens and survival times for vaccinated and control mice were compared using the Kaplan-Meier method. Levels of significance of the differences between groups were determined by the Student's unpaired $t$ test. Two-sided $P$ values $<0.05$ were considered to indicate statistical significance. Tests of normality for the data within each group were analyzed by the Shopiro-Vilk, $P$ values were $>0.10$.

\section{Results}

\section{Sera antibodies responses}

Significantly high levels of IgA were detected in the sera from all immunized mice except the RON2 group when compared with the controls $(P<0.05$ or $P<0.01)$. Among the immunized groups, the highest titer was generated in the A1+R2 group, which was higher than the single peptide groups and $A 1+R 2+R 4$ group $(P<0.05)$ (Figure 1A). All mice immunized with peptides developed higher total IgG levels, followed in order by the $\mathrm{A} 1+\mathrm{R} 2, \mathrm{~A} 1+\mathrm{R} 4$ and $\mathrm{R} 2+\mathrm{R} 4$ groups, in comparison to either control group, RON2 group or RON4 group $(P<0.05$ or $P<0.01)$ (Figure $1 \mathrm{~B})$. The distributions of serum IgG1 and IgG2a are shown in Figure $2 \mathrm{C}$. With the exception of the levels of IgG2a of mice from the RON2 and RON4 groups, the IgG1 and IgG2a levels of immunized mice were significantly higher than those of the control group $(P<0.05)$.

\section{Spleen cell proliferation responses in vitro}

Spleen cells from 8 groups of mice were prepared 2 weeks after the last immunization to assess the proliferative responses to the peptides. As shown in Table 2, the splenocyte stimulation indices (SI) from the immunized groups were higher than that of the PBS group $(P<0.01)$. A $1+\mathrm{R} 2$ immunization had the strongest activity vs all other groups. In addition, splenocytes from each experimental and control group proliferated well in response to the ConA (data not shown).

\section{Cytokines production in vitro}

The cell-mediated immunity produced in the immunized mice was evaluated by measuring the amount of cytokines (IFN- $\gamma$, IL-2, IL-4 and IL-10) in the supernatants of stimulated splenocyte cultures from mice of all groups. As shown in Table 2, significantly high levels of IFN- $\gamma$, IL- 2 and IL-4 were detected in mice from all immunized groups compared with the control $(P<0.05)$. In addition, mice immunized with $\mathrm{A} 1+\mathrm{R} 2$ had highest levels of IFN- $\gamma$, IL- 2 and IL-4 than those of the single and mixture peptide groups $(P<0.05)$. However, the production of IL-10 did not statistically differ among all groups $(P>0.05)$.

\section{SIgA production in mucosal washes}

The titers of SIgA in the nasal, vesical and intestinal washes of immunized mice were analyzed two weeks after the last immunization. Significantly higher titers of SIgA were detected in the mucosal washes from all immunized mice compared with the control $(P<0.05$ or $P<0.01)$. As shown in Figure $2 \mathrm{~A}$, the mice immunized with peptides cocktail, especially $A 1+R 2$, produced higher levels of SIgA in nasal washes $(P<0.05)$. Among the three single peptide groups, the highest titer was 

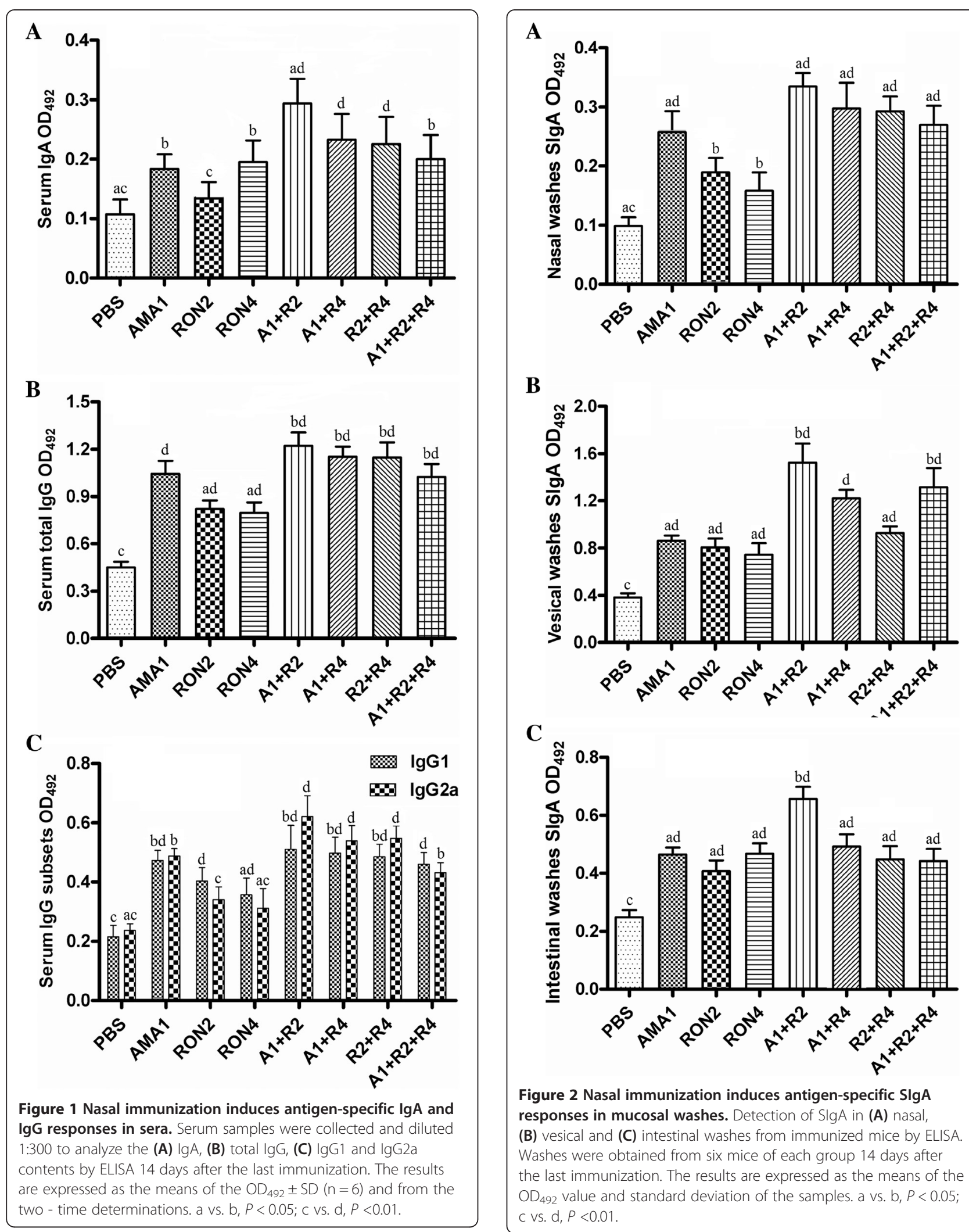

B

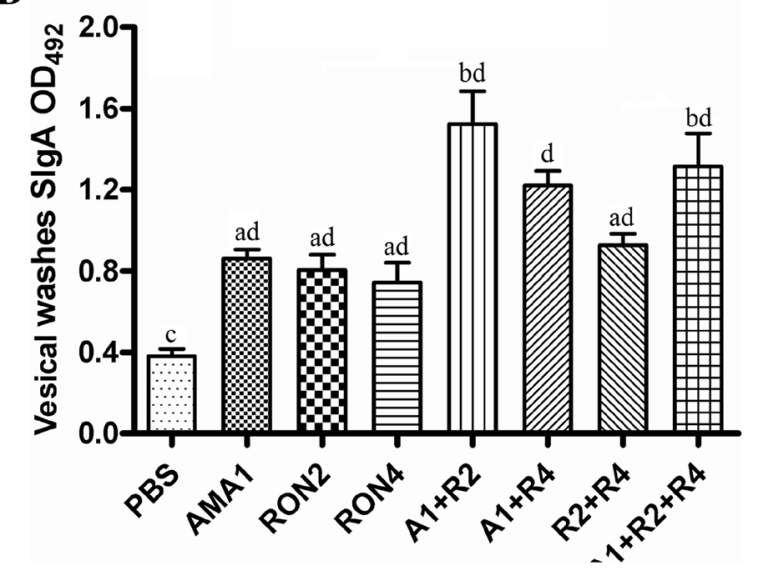

C

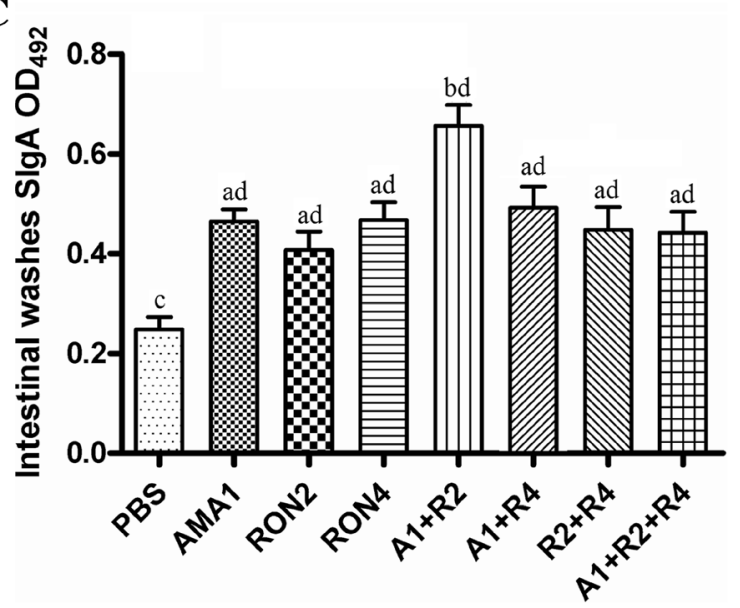

Figure 2 Nasal immunization induces antigen-specific SlgA responses in mucosal washes. Detection of SlgA in (A) nasal, (B) vesical and (C) intestinal washes from immunized mice by ELISA. Washes were obtained from six mice of each group 14 days after the last immunization. The results are expressed as the means of the $\mathrm{OD}_{492}$ value and standard deviation of the samples. a vs. $\mathrm{b}, P<0.05$; c vs. $d, P<0.01$. 
Table 2 Lymphocyte proliferation and cytokine production by splenocytes stimulated with peptides

\begin{tabular}{|c|c|c|c|c|c|}
\hline \multirow[t]{2}{*}{ Groups" } & \multirow[t]{2}{*}{ Lymphocyte SI $^{\# \#}$} & \multicolumn{4}{|c|}{ Cytokine production $(\mathrm{pg} / \mathrm{ml})^{\# \#}$} \\
\hline & & IFN- $\gamma$ & IL-2 & IL-4 & IL-10 \\
\hline PBS & $0.76 \pm 0.04 a$ & $54.96 \pm 12.07 \mathrm{a}$ & $57.17 \pm 8.64 \mathrm{a}$ & $67.17 \pm 6.43 a$ & $84.13 \pm 6.43$ \\
\hline AMA1 & $2.04 \pm 0.12 c$ & $103.09 \pm 18.99 b$ & $156.58 \pm 12.47 b$ & $147.75 \pm 11.67 b$ & $102.25 \pm 14.67$ \\
\hline RON2 & $2.14 \pm 0.24 c$ & $97.39 \pm 13.21 b$ & $147.33 \pm 11.92 b$ & $136.42 \pm 19.22 b$ & $100.55 \pm 19.22$ \\
\hline RON4 & $2.21 \pm 0.19 c$ & $94.53 \pm 16.60 b$ & $134.42 \pm 16.30 b$ & $145.58 \pm 12.98 b$ & $97.75 \pm 12.98$ \\
\hline$A 1+R 2$ & $3.17 \pm 0.35 c$ & $156.62 \pm 17.25 c$ & $219.71 \pm 17.11 c$ & $190.17 \pm 21.11 c$ & $110.13 \pm 11.11$ \\
\hline$A 1+R 4$ & $2.21 \pm 0.31 \mathrm{c}$ & $116.52 \pm 16.60 b$ & $183.84 \pm 14.62 c$ & $172.08 \pm 16.22 b$ & $111.51 \pm 16.22$ \\
\hline$R 2+R 4$ & $2.24 \pm 0.40 c$ & $123.36 \pm 16.21 b$ & $165.75 \pm 24.20 b$ & $174.83 \pm 41.98 b$ & $110.81 \pm 11.98$ \\
\hline$A 1+R 2+R 4$ & $2.54 \pm 0.32 c$ & $108.52 \pm 21.21 b$ & $162.34 \pm 17.11 b$ & $174.17 \pm 21.11 b$ & $109.75 \pm 11.11$ \\
\hline
\end{tabular}

$\# n=6$ per group.

\#\#Splenocytes from mice were harvested 2 weeks after the last immunization. SI represents stimulation index, calculated as the ratio of the OD 450 of stimulated cells to the $\mathrm{OD}_{450}$ of unstimulated cells. The values for IFN- $\gamma$ were obtained at $96 \mathrm{~h}$, while the values for IL-2 and IL- 4 were obtained at $24 \mathrm{~h}$, and the values for IL-10 were obtained at $72 \mathrm{~h}$. The results are presented as the mean $\pm \mathrm{SD}$ of three replicate experiments. a vs $\mathrm{b}: P<0.05 ; \mathrm{b}$ vs $\mathrm{c}: P<0.05$; a vs $\mathrm{c}: P<0.01$.

generated in the AMA1 group and the lowest was RON4 group.

The A1 + R2 immunized mice developed the highest levels of SIgA in the vesical washes among all groups. Moreover, the level of SIgA in the vesical washes of mice immunized with the three mixtures $(A 1+R 2+R 4)$ was higher than those of the single peptide groups and the $\mathrm{R} 2+\mathrm{R} 4$ group $(P<0.05)$ (Figure $2 \mathrm{~B})$. As depicted in Figure $2 \mathrm{C}$, the highest levels of SIgA were detected in the intestinal washes of mice immunized with $A 1+R 2$, which were significantly higher than those of the other groups $(P<0.05$ or $P<0.01)$.

Protection against nonlethal and lethal $T$. gondii infection To evaluate the efficacy of the peptide antigens against $T$. gondii infection, the numbers of tachyzoites in the livers and brains in the mice were determined one month postperoral challenge. As shown in Figure 3, the tachyzoite loads in the liver and brain of all mice immunized with peptides were significantly lower than those in the PBS group $(P<0.05)$. Furthermore, the lowest tachyzoite loads in liver and brain were observed in the A1 + R2 group $(P<0.01)$; their reduction rates were $55.79 \%$ and $55.68 \%$, respectively, when compared to the PBS group. Additionally, the reduction among the immunized groups did not statistically differ.

The survival rates of the mice were recorded daily following oral challenge for 30 days. The survival curves of all groups of mice are shown in Figure 4. Although the survival rate of all mice immunized with peptides were extended compared to mice from the control group, which died within 13 days, the survival rates of A1 + R2 (70\%), AMA1 (60\%), A1 + R2 + R4 (50\%) and RON2 (40\%) immunization reached significant level $(P<0.05)$.

\section{Discussion}

Epitope-based vaccines should contain both T- and B-cell epitopes that will serve to induce proper immune responses
[33]. In the present study, we focused on the AMA1, RON2 and RON4 involved in the invasion of Toxoplasma gondii. We predicted the potential T/B combined epitopes of TgAMA1, TgRON2 and TgRON4 by the bioinformatics method and evaluated the immune responses and protective efficacy of a single peptide or mixtures of peptides by contrast.

As a mucosal pathogen, the natural site of $T$. gondii infection is the mucosal surface where it can replicate efficiently [34]. By taking advantage of the common mucosal immune system (CMIS) [35], mucosal vaccination can elicit immune responses in multiple mucosal effector sites that are far from the immunization site [36]. Therefore, preventing infection at these sites via mucosal active vaccines is a promising and rational approach for vaccine development. Intranasal immunization is an effective and safe way of providing a disseminated mucosal immunity as well as systemic immunity [23,37].

An efficient mucosal vaccine should promote both mucosal and systemic immune responses [35,38]. The mucosal immune system can induce potent protective immunity against harmful pathogens to avoid mucosal colonization and pathogen invasion [39]. Secretory IgA (SIgA) is the main humoral mediator of the mucosal first-line defense system, and it is locally produced in the effector tissues of the mucosal immune system [40]. To evaluate mucosal immune responses, the levels of antigen-specific SIgA in the nasal, vesical and intestinal washes of immunized mice were examined in this study. We found a strong SIgA antibody response in the nasal and vesical washes of mice immunized with peptides. Moreover, the levels of SIgA in washes of mice immunized with mixtures of peptides, especially the A1 + R2 mixture, were significantly enhanced compared to the single peptide immunization. The intestinal IgA system is the best-understood contributor to mucosal immunity. In our study, the strongest SIgA antibody response in 


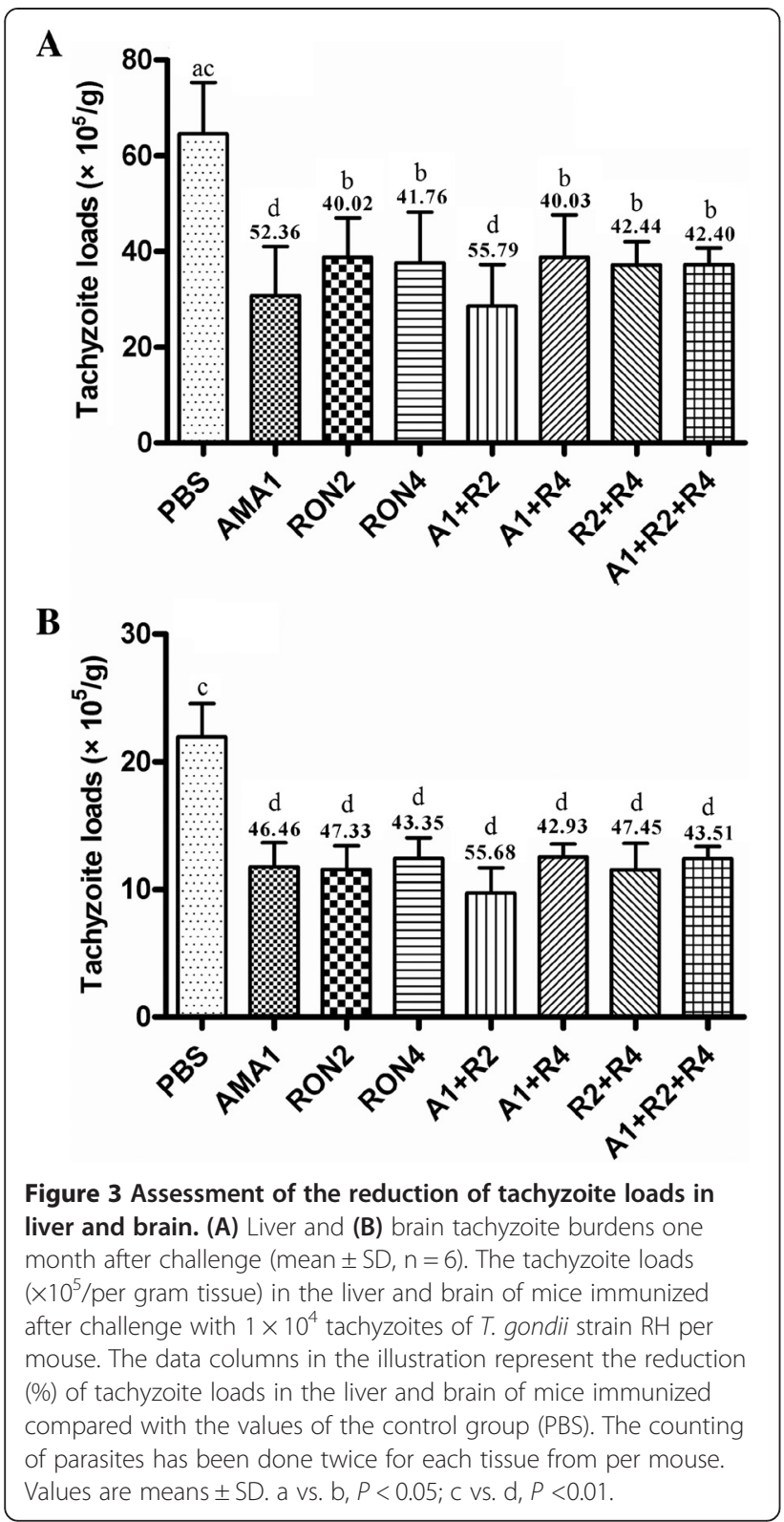

the intestinal washes was observed in mice immunized with $\mathrm{A} 1+\mathrm{R} 2$. Taken together, the above results imply that a mixture of peptides, especially the mixture of two peptides $(A 1+R 2)$, was more effective in eliciting a mucosal immune response than a single peptide. Moreover, SIgA antibodies have been shown to reduce $T$. gondii infection of human enterocytes in vitro, which suggests that SIgA secretion is also important in defending against pathogen invasion into the intestinal mucosa $[41,42]$.

System immunity plays a significant role in the defense against pathogens. Consistent with previous reports $[42,43]$, our results showed that mice immunized with peptides had high specific IgG and IgA antibodies in sera. Moreover, the reactions of IgG and IgA of mice

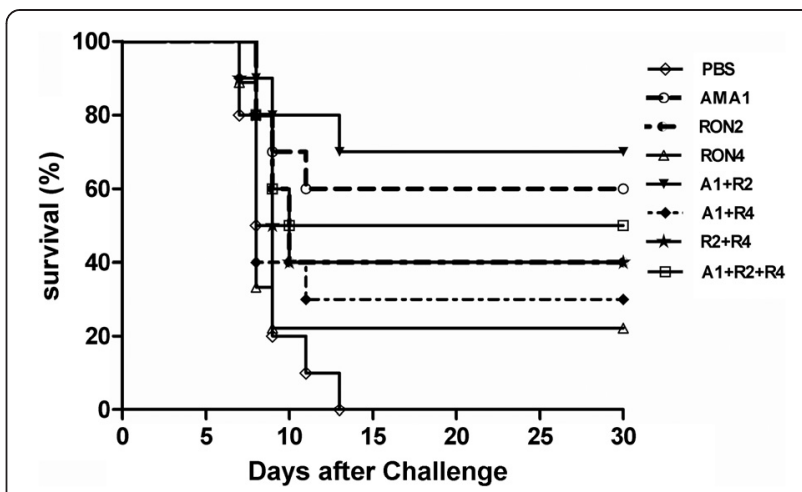

Figure 4 Evaluation of survival curves against the lethal challenge. Survival curves of immunized mice of the 8 groups $(n=10)$ were monitored daily after challenge with $4 \times 10^{4}$ tachyzoites of $\mathrm{T}$. gondii $\mathrm{RH}$ strain for 30 days post-challenge.

immunized with peptide mixtures were significantly enhanced compared to the single peptide immunization. Specific antibodies seem to be important in controlling T. gondii infection because the antibodies produced by $\mathrm{B}$ cells inhibit the attachment of the parasites to the host cell receptors, and macrophages kill intracellular Abcoated tachyzoites $[44,45]$. Additionally, the splenocyte from the peptide immunized mice proliferated more rapidly than those of the control group, and the mice immunized with A1 + R2 showed the strongest increase.

Ideal vaccine candidates should induce both protective cellular Th1 and humoral Th2 responses [46]. The immune regulatory factors IFN- $\gamma$, IL- 2 and IgG2a are associated with Th1-type responses, and IL-4, IL-10 and IgG1 are associated with Th2-type responses $[47,48]$. In this study, mice immunized with the peptides exhibited a mixed Th1/Th2 response with high titers of antigenspecific IgG1 and IgG2a antibodies. Our results showed that immunization with mixtures of $\mathrm{A} 1+\mathrm{R} 2$ peptides can enhance the Th1 or Th2 mediated immunity, as evidenced by high levels of IFN- $\gamma$, IL- 2 or IL-4 compared with the control group or single peptide groups. However, the production of IL-10 was not statistically different between different groups $(P>0.05)$. Thus IFN- $\gamma$-mediated immune responses are necessary to control both the acute and chronic phases of T. gondii infection [49,50]. IL-4 may be involved in controlling $T$. gondii tachyzoites in the brain [51].

During the evaluation of protection potency, the highly virulent RH strain of $T$. gondii was used as the challenging infection in this study. All mice immunized with peptides showed significantly protective efficacy against nonlethal $T$. gondii infection compared with the control $(P<0.05)$. Furthermore, the mice immunized with $\mathrm{A} 1+$ R2, AMA1, A1 + R2 + R4 and RON2 against lethal $T$. gondii infection showed a significantly higher survival rate $(P<0.05)$; in particular the mice immunized with 
$\mathrm{A} 1+\mathrm{R} 2$ showed the highest reduction of tachyzoite loads in the liver (55.79\%) and the brain (55.68\%). These results were consistent with previous reports that indicated that a DNA vaccine expressing RON4 and recombinant protein RON4 vaccine failed to protect the mice against oral challenge with $T$. gondii cysts [19].

A growing body of current research has focused on cocktail or multi-antigenic vaccines [18,52]. The enhanced immune responses and protective efficacy induced by mixtures of peptides in this study, especially $\mathrm{A} 1+\mathrm{R} 2$, coincide with the results of the above-described studies, and the results also indicated that AMA1-RON2 interaction may play a key role in invasion by Toxoplasma gondii. This means that the combination of AMA1 and RON2 would be a better solution to fight against $T$. gondii induced immune reaction.

It is worth noting that the enhanced immune responses and protective efficacy induced by mixtures of two peptides, especially AMA1 and RON2 mixture, were more powerful and efficient than the mixture of three peptides. What are the reasons leading to this result? The analysis of the factors showed that the doses of mixture of three peptides group (10 $\mu$ g each peptide) were less than doses of mixture of two peptides $(15 \mu \mathrm{g}$ each peptide) and it suggests that when antigen dose is too low, even if the three antigens are mixed, a better immune effect is not achieved.

\section{Conclusions}

The intranasal immunization of mice with a single peptide (AMA1, RON2, RON4) or a mixture of peptides $(\mathrm{A} 1+\mathrm{R} 2, \mathrm{~A} 1+\mathrm{R} 4, \mathrm{R} 2+\mathrm{R} 4$ and $\mathrm{A} 1+\mathrm{R} 2+\mathrm{R} 4)$ has been shown to induce effective mucosal and systemic immune responses and to elicit partial protection against acute and chronic $T$. gondii infection. Moreover, our study indicated that a mixture of peptides, especially the A1 + R2 mixture, was more powerful and efficient than a single peptide. These results demonstrated that AMA1, RON2 and RON4 containing $\mathrm{T}$ - and $\mathrm{B}$-cell epitopes can be considered possible candidate antigens against toxoplasmosis, and a combination of peptides as a mucosal vaccine strategy is essential for future Toxoplasma vaccine development.

\section{Competing interests}

The authors declare that they have no competing interests.

\section{Authors' contributions \\ GRY and HLW conceived and designed the study, and GRY critically revised the manuscript; TEZ, LTY, RHL, and XLM performed experiments; TEZ analyzed the data and drafted the first manuscript draft. All authors read and approved the final manuscript.}

\section{Acknowledgments}

This work was supported by the National Natural Science Foundation of China (Grant No. 81071374) and the Shanxi Provincial Natural Science Foundation (Grant No. 2013011059-4). We thank Liang-Liang Chen, Class
S0803, the Second School of Clinical Medicine from Shanxi Medical University, who contributed to animal experiments of this study.

\section{Author details}

${ }^{1}$ Research Institute of Medical Parasitology, Shanxi Medical University, Xinjian South Road, Taiyuan, Shanxi Province 030001, China. ${ }^{2}$ Department of Clinical Laboratory, Central Hospital of the 12th Bureau Group of China Railway, Taiyuan, Shanxi 030053, China. ${ }^{3}$ Department of physiology, Key Laboratory of Cellular Physiology Co-constructed by Province and Ministry of Education, Shanxi Medical University, Taiyuan, Shanxi 030001, China. ${ }^{4}$ Department of Biology, Taiyuan Normal University, Taiyuan, Shanxi 030031, China.

Received: 17 July 2014 Accepted: 2 January 2015

Published online: 13 January 2015

\section{References}

1. Dubey JP, Lindsay DS, Speer CA. Structures of Toxoplasma gondii tachyzoites, bradyzoites, and sporozoites and biology and development of tissue cysts. Clin Microbiol Rev. 1998;11:267-99.

2. Derouin F, Pelloux H. Prevention of toxoplasmosis in transplant patients. Clin Microbiol Infect. 2008;14:1089-101.

3. Innes EA. A brief history and overview of Toxoplasma gondii. Zoonoses Public Health. 2010;57:1-7.

4. Tenter AM, Heckeroth AR, Weiss LM. Toxoplasma gondii: from animals to humans. Int J Parasitol. 2000;30:1217-58.

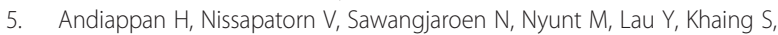
et al. Comparative study on Toxoplasma infection between Malaysian and Myanmar pregnant women. Parasites Vectors. 2014;7:564-77.

6. lijima H, Takahashi I, Kiyono H. Mucosal immune network in the gut for the control of infectious diseases. Rev Med Virol. 2001;11:117-33.

7. Jongert E, Roberts CW, Gargano N, Förster-Waldl E, Petersen E. Vaccines against Toxoplasma gondii: challenges and opportunities. Mem Inst Oswaldo Cruz. 2009;104:252-66.

8. Mital J, Meissner M, Soldati D, Ward GE. Conditional expression of Toxoplasma gondii apical membrane antigen-1 (TgAMA1) demonstrates that TgAMA1 plays a critical role in host cell invasion. Mol Biol Cell. 2005;16:4341-9.

9. Crawford J, Tonkin ML, Grujic O, Boulanger MJ. Structural characterization of apical membrane antigen 1 (AMA1) from Toxoplasma gondii. J Biol Chem. 2010;285:15644-52.

10. Santos JM, Ferguson DJ, Blackman MJ, Soldati-Favre D. Intramembrane cleavage of AMA1 triggers Toxoplasma to switch from an invasive to a replicative mode. Science. 2010;331:473-7.

11. Tyler JS, Treeck M, Boothroyd JC. Focus on the ringleader: the role of AMA1 in apicomplexan invasion and replication. Trends Parasitol. 2011;27:410-20.

12. Alexander DL, Mital J, Ward GE, Bradley P, Boothroyd JC. Identification of the moving junction complex of Toxoplasma gondii: a collaboration between distinct secretory organelles. PLoS Pathog. 2005;1:e17.

13. Besteiro S, Michelin A, Poncet J, Dubremetz J-F, Lebrun M. Export of a Toxoplasma gondii rhoptry neck protein complex at the host cell membrane to form the moving junction during invasion. PLoS Pathog. 2009;5:e1000309.

14. Lamarque M, Besteiro S, Papoin J, Roques M, Vulliez-Le Normand B, Morlon-Guyot J, et al. The RON2-AMA1 interaction is a critical step in moving junction dependent invasion by apicomplexan parasites. PLoS Pathog. 2011;7:e1001276.

15. Tyler JS, Boothroyd JC. The C-terminus of Toxoplasma RON2 provides the crucial link between AMA1 and the host-associated invasion complex. PLoS Pathog. 2011;7:e1001282.

16. Lebrun M, Michelin A, El Hajj H, Poncet J, Bradley PJ, Vial H, et al. The rhoptry neck protein RON4 relocalizes at the moving junction during Toxoplasma gondii invasion. Cell Microbiol. 2005;7:1823-33.

17. Dautu G, Munyaka B, Carmen G, Zhang G, Omata Y, Xuenan X, et al. Toxoplasma gondii: DNA vaccination with genes encoding antigens MIC2, M2AP, AMA1 and BAG1 and evaluation of their immunogenic potential. Exp Parasitol. 2007;116:273-82.

18. Srinivasan $P$, Beatty WL, Diouf A, Herrera R, Ambroggio X, Moch JK, et al. Binding of Plasmodium merozoite proteins RON2 and AMA1 triggers commitment to invasion. Proc Natl Acad Sci U S A. 2011;108:13275-80.

19. Rashid I, Hedhli D, Moiré N, Pierre J, Debierre-Grockiego F, Dimier-Poisson I, et al. Immunological responses induced by a DNA vaccine expressing RON4 
and by immunogenic recombinant protein RON4 failed to protect mice against chronic toxoplasmosis. Vaccine. 2011;29:8838-46.

20. Wang $Y$, Wang M, Wang G, Pang A, Fu B, Yin H, et al. Increased survival time in mice vaccinated with a branched lysine multiple antigenic peptide containing B- and T-cell epitopes from T. gondii antigens. Vaccine. 2011;29:8619-23

21. Zhao G, Zhou A, Lv G, Meng M, Sun M, Bai Y, et al. Toxoplasma gondii cathepsin proteases are undeveloped prominent vaccine antigens against toxoplasmosis. BMC Infect Dis. 2013;13:207.

22. Wu HY, Russell MW. Nasal lymphoid tissue, intranasal immunization, and compartmentalization of the common mucosal immune system. Immunol Res. 1997;16:187-201.

23. Wang $H L$, Pang $M$, Yin $L T$, Zhang $J H$, Meng $X L$, Yu BF, et al. Intranasal immunisation of the recombinant Toxoplasma gondii receptor for activated C kinase 1 partly protects mice against T. gondiiin fection. Acta Trop. 2014;137:58-66.

24. Wang HL, Li YQ, Yin LT, Meng XL, Guo M, Zhang JH, et al. Toxoplasma gondii protein disulfide isomerase (TgPDI) is a novel vaccine candidate against toxoplasmosis. PLoS One. 2013;8:e70884.

25. Yin $L T$, Hao HX, Wang HL, Zhang JH, Meng XL, Yin GR. Intranasal immunisation with recombinant Toxoplasma gondii actin partly protects mice against toxoplasmosis. PLoS One. 2013;8:e82765.

26. Igarashi M, Zulpo DL, Cunha IA, Barros LD, Pereira VF, Taroda A, et al. Toxoplasma gondii: humoral and cellular immune response of BALB/c mice immunized via intranasal route with rTgROP2. Rev Bras Parasitol Vet. 2010;19:210-6.

27. Yang JM, Wang HJ, Du L, Han XM, Ye ZY, Fang $Y$, et al. Screening and identification of novel $B$ cell epitopes in human heparanase and their anti-invasion property for hepatocellular carcinoma. Cancer Immunol Immunother. 2009;58:1387-96.

28. Zhang ZW, Zhang YG, Wang YL, Pan L, Fang YZ, Jiang ST, et al. Screening and identification of $B$ cell epitopes of structural proteins of foot-and-mouth disease virus serotype Asia1. Vet Microbiol. 2010;140:25-33.

29. Bai Y, He S, Zhao G, Chen L, Shi N, Zhou H, et al. Toxoplasma gondii: Bioinformatics analysis, cloning and expression of a novel protein TgIMP1. Exp Parasitol. 2012;132:458-64.

30. Yu H, Huang B, Zhuo X, Chen X, Du A. Evaluation of a real-time PCR assay based on the single-copy SAG1 gene for the detection of Toxoplasma gondii. Vet Parasitol. 2013;197:670-3.

31. Cisney ED, Fernandez S, Hall SI, Krietz GA, Ulrich RG. Examining the role of nasopharyngeal-associated lymphoreticular tissue (NALT) in mouse responses to vaccines. J Vis Exp. 2012;1:3960.

32. Goldoni AL, Maciel Jr M, Rigato PO, Piubelli O, de Brito CA, Melo A, et al. Mucosal and systemic anti-GAG immunity induced by neonatal immunization with HIV LAMP/gag DNA vaccine in mice. Immunobiology. 2011;216:505-12.

33. Cong H, Gu QM, Yin HE, Wang JW, Zhao QL, Zhou HY, et al. Multi-epitope DNA vaccine linked to the $A 2 / B$ subunit of cholera toxin protect mice against Toxoplasma gondii. Vaccine. 2008;26:3913-21.

34. Kasper L, Courret N, Darche S, Luangsay S, Mennechet F, Minns L, et al. Toxoplasma gondii and mucosal immunity. Int J Parasitol. 2004;34:401-9.

35. Fujkuyama Y, Tokuhara D, Kataoka K, Gilbert RS, McGhee JR, Yuki Y, et al. Novel vaccine development strategies for inducing mucosal immunity. Expert Rev Vaccines. 2012;11:367-79.

36. Brandtzaeg P. Induction of secretory immunity and memory at mucosal surfaces. Vaccine. 2007;25:5467-84.

37. Velge-Roussel F, Marcelo P, Lepage AC, Buzoni-Gatel D, Bout DT. Intranasal immunization with Toxoplasma gondii SAG1 induces protective cells into both NALT and GALT compartments. Infect Immun. 2000;68:969-72.

38. Gebril A, Alsaadi M, Acevedo R, Mullen AB, Ferro VA. Optimizing efficacy of mucosal vaccines. Expert Rev Vaccines. 2012;11:1139-55.

39. Anjuère F, Czerkinsky C. Mucosal immunity and vaccine development. Med Sci (Paris). 2007;23:371-8.

40. Brandtzaeg P. The Mucosal immune system and its integration with the mammary glands. J Pediatr. 2010;156(2 Suppl):S8-15.

41. Mack DG, McLeod R. Human Toxoplasma gondii-specific secretory immunoglobulin A reduces T. gondii infection of enterocytes in vitro. J Clin Invest. 1992;90:2585-92.

42. Zorgi NE, Costa A, Galisteo Jr AJ, do Nascimento N, de Andrade Jr HF. Humoral responses and immune protection in mice immunized with irradiated T.gondii tachyzoites and challenged with three genetically distinct strains of T.gondii. Immunol Lett. 2011;138:187-96.

43. Stanley AC, Buxton D, Innes EA, Huntley JF. Intranasal immunisation with Toxoplasma gondii tachyzoite antigen encapsulated into PLG microspheres induces humoral and cell-mediated immunity in sheep. Vaccine. 2004;22:3929-41.

44. Kang H, Remington JS, Suzuki Y. Decreased resistance of B cell deficient mice to infection with Toxoplasma gondii despite unimpaired expression of IFN-gamma: TNF-alpha, and inducible nitric oxide synthase. J Immunol. 2000;164:2629-34.

45. Sayles PC, Gibson GW, Johnson LL. B cells are essential for vaccination-induced resistance to virulent Toxoplasma gondii. Infect Immun. 2000;68:1026-33.

46. Kur J, Holec-Gasior L, Hiszczynska-Sawicka E. Current status of toxoplasmosis vaccine development. Expert Rev Vaccines. 2009;8:791-808.

47. Pulendran B. Modulating $\mathrm{TH} 1 / \mathrm{TH} 2$ responses with microbes, dendritic cells, and pathogen recognition receptors. Immunol Res. 2004;29:187-96.

48. Mosmann TR, Li L, Hen gartner H, Kagi D, Fu W, Sad S. Differentiation and functions of T cell subsets. Ciba Found Symp. 1997;204:148-54. discussion 154-158.

49. Jongert E, Lemiere A, Van Ginderachter J, De Craeye S, Huygen K, D'Souza S Functional characterization of in vivo effector $\mathrm{CD} 4(+)$ and $\mathrm{CD} 8(+) \mathrm{T}$ cell responses in acute toxoplasmosis: an interplay of IFN-gamma and cytolytic T cells. Vaccine. 2010;28:2556-64.

50. Suzuki Y, Sa Q, Gehman M, Ochiai E. Interferon-gamma- and perforin-mediated immune responses for resistance against Toxoplasma gondii in the brain. Expert Rev Mol Med. 2011;13:e31.

51. Suzuki Y, Yang Q, Yang S, Nguyen N, Lim S, Liesenfeld O, et al. IL-4 is protective against development of Toxoplasmic encephalitis. J Immunol. 1996;157:2564-9.

52. Fang R, Feng $H$, Hu M, Khan MK, Wang L, Zhao J. Evaluation of immune responses induced by SAG1 and MIC3 vaccine cocktails against Toxoplasma gondii. Vet Parasitol. 2012;187:140-6.

\section{Submit your next manuscript to BioMed Central and take full advantage of:}

- Convenient online submission

- Thorough peer review

- No space constraints or color figure charges

- Immediate publication on acceptance

- Inclusion in PubMed, CAS, Scopus and Google Scholar

- Research which is freely available for redistribution

Submit your manuscript at www.biomedcentral.com/submit
C) Biomed Central 